УДК 004.774.6Блог:316.77=811.111

DOI https://doi.org/10.31470/2518-7600-2021-12-238-254

\title{
BLOGS AS NEW MEANS IN MODERN COMMUNICATION
}

\section{БЛОГИ ЯК НОВІ ЗАСОБИ В СУЧАСНІЙ КОМУНІКАЦЇ}

\section{БЛОГИ КАК НОВЫЕ СРЕДСТВА В СОВРЕМЕННОЙ КОМУНИКАЦИИ}

\section{Марина Навальна,}

доктор філологічних наук, професор кафедри

журналістики та мовної комунікації

mnavalna@gmail.com

https://orcid.org/0000-00025064-3122 Начіональний університет біоресурсів $i$ природокористування Украӥни, м. Київ, вул. Героӥв Оборони, 15, Украӥна, 03041
Maryna Navalna,

Doctor in Philological Sciences, Professor of Department of Journalism and Language Communication mnavalna@gmail.com https://orcid.org/0000-00025064-3122 National University of Life and Environmental Sciences of Ukraine, 15, Heroiv Oborony St., Kyiv, Ukraine, 03041

\section{АНОТАЦІЯ}

Інформаційна сфера останнього десятиліття реалізувалася в інтеграчї різних способів комунікації в інтерактивні інформаційні мережі. Об'єднання в одній системі текстів, зображень, символів та звуків в глобальній мережі $i$ за умови доступного $i$ недорогого доступу, кардинально змінює характер соиіальних комунікації.

Історія журналістики має свої етапи розвитку: від давніх до сучасних форм, від знаків до сучасних інформаційних технологій. Якщцо попередні століття відповідним чином 
описані $і$ проаналізовані дослідниками, то нові засоби комунікації потребують окремих досліджень.

У пропонованій студії здійснено спробу проаналізувати блоги як нові засоби в сучасній комунікації.

Блогерство - вирізняється від журналістики тим, щзо в ньому домінантною $є$ комунікативна функція, щзо $в$ традииійних засобах масової комунікації $\epsilon$ лише під час прямого ефіру на радіо, телебаченні, але часто цензурована інформачія модератором, редактором, який визначає кого, коли випустити в ефір.

У розвідиі акцентується увага на тому, чи є блог видом нової журналістики чи новим журналістським жанром, який увійшов у масову комунікацію.

У статті як прикладний аспект розглянуто десять найпопулярніших украӥнських блогерів в Instagram за результатами аналізу інтернет-видань.

Зроблено висновки, щуо блоги є потужними виробниками інформачіі $i$, як наслідок, кореляторами мережевих інформаційних потоків.

Блогерство $i$ журналістика - два види масової інформаційно-комунікаційної діяльності, між якими є спільне й відмінне, але обидва види мають моральну відповідальність за контент.

Інтернет-сайти та соціальні мережі систематично подають рейтинги найпопулярніших блогів. У таких випадках подають автора, його вік, кількість підписників, теми $i$ коротку історію автора, зазичай подають деталі приватного жсття блогерів. Така структура подачі матеріалу приваблює увагу споживача інформачії.

Ключові слова: блог, особистий блог, тематичний блог, історичні етапи журналістики, комунікація, нові медіа, нові комунікаційні технологіі, Інтернет.

Formulation of the problem. On the scale of all mankind, the development of a new communication system and new media 
continues, they are often seen as a union of interactive communication technologies and digital broadcasting, in which the Internet becomes the main mediator. This process acts as a basis for changing the conditions of interaction, it is not just a technical or technological, but also a socio-cultural process. Therefore, new media came into the focus of sociological research and today they are analyzed in the concepts of transformation of modern society as ones of the key factors. The communicative revolution of the $\mathrm{XX}$ century provided audiovisual culture with a historical rematch over written discourse. The noble alphabetical order first in movies and radio, then in television yields to sensual, non-reflective communication. The technological transformation of no less scale took place at the turn of the century. It is embodied in the integration of various ways of communication in interactive information networks. In other words, supertext and metalanguage are formed, combining written, oral, and audiovisual means of communication for the first time in history.

The information scope of the last decade has been realized in the integration of various ways of communication into interactive information networks. Combining texts, images, symbols and sounds in one system in a global network and providing accessible and inexpensive access, dramatically changes the nature of social communication.

The history of mass media development is not only the history of technical innovations, but their formation is also connected with grand social innovations. Mass media is a relatively new social institution, its function is to produce and disseminate knowledge in the broadest sense of the word. The most significant characteristics of this relatively new institution are: 1) like most modern institutions, the mass media is an institutional and organizational unity; 2) the institute of mass media performs a special, unique function of creating an informative analogue of society by building a definite picture of the world, as well as covering the functioning of other social institutions; 3 ) acting as a leader of public opinion, the institution of mass communication by virtue of its mobilizing 
potential - the ability to influence large groups of people plays a special role in the modern political process. The stages of development of mass media are most closely connected with the changes of society. The urbanization, rising living standards and increasing leisure time, the formation of a modern bureaucracy and other global socio-cultural processes would be impossible in the absence of mass media, which are not only one of the symbols of the modern world but also a very active catalyst for social change.

The term «new media» first appeared at the end of the last century. Until the 1980 s, the basis for the media-periodicals, radio and television were analog and print media. However, with the rapid development of digital, network, computer, information, gaming, technologies and communications, the media have undergone significant transformations. Based on new, digital media, directly related to the evolution of computers and the Internet, widely implemented in various fields, they have become more interactive than traditional, which also differed significantly from them. However, at the beginning of the emergence of new media, the term was often understood as the actual process of emergence and progress of digital and network technologies and communications.

Among a number of new means of popularity, blogging is gaining popularity as an voluntary, informal, unbiased information through social networks, Internet media, and Internet versions of traditional mass media. Therefore, there is a need of a detailed study of this new means of communication.

Analysis of recent research and publications. The issues are studied by Y. Kiss in the article «Blog is an informal journalism» (Kissa, 2020); L. Eckhard in the article «Blogging is a civic journalism or rumors» (Eckhard, 2010). M. Semenchenko called blogging a journalism without journalists (Semenchenko, 2011). O. Ivanova in her dissertation research «Professionalizing onlinejournalism in the blogosphere» considers blog journalism as a subgroup of online journalism, identifies the internal structure of the professional group of blog journalists, assesses the features of this structure, form and development tendencies (Ivanova, 2011). 
The topic of blogging and journalism is covered by B. V. Potiatynyk in the book «Internet-journalism in the aspect of anonymity of blog authors, compliance with legal and ethical norms» (Potiatynyk, 2011). The study of the content of blogs in Ukraine, the emergence of new media bloggers continue to interest researchers in various aspects.

Research methodology. The study used methods of collecting information, describing reality based on observations, as well as the method of analyzing information material.

The purpose of the study is to understand the status of new communications in the modern socio-cultural space, in particular to identify and determine the features of blogs, the benefits of blogging, to reveal the conditions of its identity with journalism.

Presentation of the main research material. The journalism is a professional activity in the mass media, which is taught in higher education institutions, it is professional work in media, or work under an employment or other agreement or contract, a kind of literary work, the main work of collecting, recording, analyzing and presenting information in journalistic genres about socially significant facts, events, phenomena and their evaluation in order to form public opinion, and adjust the influence of decisions and actions of the government, a means of communication between the state and society.

The blogs are not mass media, simply because they do not communicate between the state and society. Blogs are a means of communication. They become mass when they have more than a thousand audience. The mass media (press, radio, television, news agencies, Internet media) as social institutions of society have their own specific social functions, are morally and legally responsible for their content. The professional journalists work in the editorial offices (about half of them have a higher professional journalistic education, the other half have a humanitarian higher education and are able to professionally create interesting text, images, audio, video materials). Every traditional media strives to have real professionals as employees. 
Anyone who has something to say can blog. The platform for blogging is the Internet, social networks and online media. There are online media that have author's blogs. There are independent author's blogs of journalists on social networks. Some blogger journalists believe that their democratic freedoms are being suppressed in newsrooms, while in blogs they have more freedom of expression and, of course, they are right. However, such blogs are popular if they are run not only by a well-known author, but also by an interesting interlocutor, an outstanding individual with a modern mindset.

In online media, online versions of traditional media, some blogs are run by professional journalists to feel the taste of recognition, the audience's reaction to their material, expand the audience of their fans, perform a communicative function in the media, find new ideas, interesting topic, relevant topic or problem, to obtain new additional information that can later be used in the material of the traditional media.

Most bloggers are not professional journalists, but people of different professions who want to communicate, express their opinion, which they do in their blogs. Of course, the content of blogs-diaries is not journalism, it is a completely different kind of creativity, some researchers call this type of activity blogging. If the information, the opinion of the blogger is uninteresting, not socially significant, that does not relate to current issues of a social group in society, then such blog is doomed to oblivion. The popularity of the blog also depends on the accuracy of assessments, clarity of opinion, relevance of positions, style of presentation, which impresses readers. The journalists are taught this in higher education, and some bloggers achieve this on their own, making their blogs the most viewed. A huge number of personal blogs have nothing to do with journalism also because they do not perform or constantly violate the social and psychological functions of the media: information, regulation, integration, education, control, education, recreation, hedonistic (pleasure), emotional relaxation, utilitarian, contact, social orientation, affiliation (belonging to a group). 
The opinion of popular bloggers coincides with the opinion of hundreds, thousands of visitors of their blogs, they feel and express it. And this is common with a journalist who understands the novelty, social significance of facts, events, phenomena and is able to distinguish them from others. Blogging is somewhat different from journalism in its predominant communicative function, which in traditional media is only available live on radio and television, but information is often censored by a moderator, an editor, who determines who to broadcast and when to do it.

According to the content, there are two classes of blogs: personal blogs, it is better to call them electronic diaries, and thematic blogs. There are loner blogs that are not affiliated with any blogging associations, but there are blogging networks. As S. Kvit notes, «One of the main trends in the development of thematic blogs today is to join blogging networks for joint promotion. It is easier to increase the readership, profits, citation index, etc. under a single brand» (Kvit, 2020). The motives for uniting bloggers are different. For some, blogging networks help increase their readership, and for others, they help increase profits. After all, most blogging networks are commercial. Blogs with thousands of audiences, information for which only several people help to collect and process, in their organization of work resemble the editorial office of the Internet media. Such blogs, thanks to high-quality, original, unbiased, verified information, later became online media. One can say about such bloggers that they made themselves journalists and created a job for themselves and others.

The blogs promote democracy, socialization of the audience, development of freedoms, including freedom of speech, freedom of the media, freedom of access to information, freedom of expression, freedom of evaluation, freedom of mass communication. The blogs, like the media, are different. There are blogs - ordinary personal diaries for the author's self-expression, and there are blogs that contain real journalistic materials.

Thus, the blogs can be used as a platform to publish journalistic material when it is not possible to publish it in 
traditional media. The blogs attract the attention of the audience as uncontrolled, interactive, high-speed media. After all, even in the Internet media there are graduation editors who filter the information and they decide: whether the material sees the world or not, put the materials after reading, which delays the flow of content to the audience. Of course, the key to a blog's popularity can be its reputation as a source of accurate, unbiased, in a word, highly moral information. Such blogs can compete with well-known media corporations. According to the research, if you do not take into account the blogs of journalists on the Internet, there will be almost no blogs that exist at the level of professional journalism.

We will describe 10 most popular Ukrainian bloggers on Instagram (10 most popular, 2020), according to the definition of an Internet resource. In such cases, the authors, their age, number of subscribers, topics and a short history of the author are shown. Here is a description of ten leaders by number of subscribers. All bloggers have over one million subscribers.

\section{Sofia Stuzhuk - 5, 6 million subscribers}

Sofia Stuzhuk, 25, has the most followed account among all well-known Ukrainian bloggers. In the blog, she talks about her life, motherhood experience, and shares beauty secrets. The famous insta-mama has both her fans who support her in everything, and haters who often criticize. At the end of 2019, the childbirth by the famous blogger shocked the network. The girl gave birth at home and showed the whole process on video. This act provoked a heated discussion on the Internet, because such births are not certified in Ukraine and, according to midwives, carry deadly risks for both women and children. Sofia is raising three children from Dmytro Stuzhuk, who recently died of coronavirus. Six months ago, after 6 years of marriage, the couple decided to divorce.

\section{Elena Venum - 4.3 million subscribers}

Elena Venum became famous on Instagram after she actively shared with subscribers tips on beauty, weight loss, healthy eating and makeup. In 2016, the girl began filming vines, which further attracted the attention of the audience. In summer, the blogger 
became a mother for the first time. Blogger Daryl is a father of the girl.

Sasha Pustovit - 1, 8 million subscribers

Sasha Pustovit is a blogger from Ivano-Frankivsk. In 2018, the girl graduated from medical school with a degree in dentistry, but chose a different path in life. In 2015, the girl married presenter and vlogger Igor Pustovit. A year later they had a son Danilo, and 2 years later the couple had a son Eugene. Recently, 25-year-old Sasha made her dream come true and opened a beauty salon. In the blog, she talks about motherhood, health, beauty and simply shares a part of her life with subscribers.

Yulia Verbynets - 1.7 million subscribers

Yulia Verbynets is another well-known blogger from IvanoFrankivsk. At a very young age, the girl was able to turn her hobby into an income, so at the age of 17 she collaborates with famous brands, travels and enjoys life.

Tetiana Parfilieva - 1,7 million subscribers

26-year-old Tetiana Parfilieva is a well-known blogger who attracts the attention of her subscribers with her pretty appearance and charisma. The girl runs a lifestyle blog in which she shares her life with fans. It is worth noting that Tetiana has her own business - clothing store Cherry Land Shop, showrooms, which are actively developing in Kyiv, Kharkiv, Dnipro and Zhytomyr. She also models for her own showroom. Tania met her husband Ivan when they were in the 9 th grade. The lovers have been together for a long time and in 2019 became husband and wife. The blogger's Instagram account is filled with stylish and romantic photos.

Dasha Kvitkova - 1,6 million subscribers

Dasha Kvitkova is the winner of the reality show "The Bachelor" on STB TV channel. In the finale, she was chosen by TV presenter Nikita Dobrynin. The couple sincerely fell in love with each other on the project, so immediately after the show ended, they began to develop their relationship outside the cameras. The couple often traveled and shared their lifestyle with subscribers. In early 2020, Nikita Dobrynin proposed to Dasha during a vacation in Bali. 
Instagram users really liked this fabulous finale, so even more people started following the girl. On August 12, a wedding took place in one of the most fashionable restaurants in Kyiv. This is the first time in the history of the Ukrainian version of the "Bachelor" the hero married a girl he chose in the finale of a reality show. Dasha Kvitkova radiates joy and happiness in her blog, so she attracts subscribers with her charisma and sincere smile.

Katia Yakymchuk - 1.5 million subscribers

A young blogger from Lutsk has long been the heroine of tabloid articles, as a 19-year-old girl bought a Porsche Cayenne and a house. Despite such a large number of subscribers, the girl has a lot of haters who accuse her of fraud. In her Instagram, the girl launched an author's course that teaches how to make money. Yes, in her profile Katia noted that in October her students earned 270 thousand hryvnias, but some students of this course note that in fact the blogger extorts money from her subscribers and shares information, which can be easily found on the Internet. Now the girl is 20 years old, in addition to the car and the house, she also has 4 stores that she opened and a pretty good income thanks to the giveaways.

\section{Tetiana Samburska - 1.3 million subscribers}

Tetiana Samburska is a smiling and sincere girl from IvanoFrankivsk, who always radiates joy and happiness on her Instagram pages. The girl often shares the photos of her family, so those who follow her are well acquainted with her parents, sister and niece. The girl often shows love to her closest ones and thanks her parents for giving her life and constantly taking care of her and helping her. In 2017, Tania's parents bought her first car, so recently the girl surprised her parents by buying them a jeep. At the age of 18, Tania opened her own beauty studio. And it was the parents who contributed to this. In the blog Samburska shares life moments, and also pleases subscribers with numerous giveaways. In 2019, the girl married her lover Ihor, who does not like publicity, does not have his Instagram, but makes the blogger very happy, because the girl often dedicates poignant posts to her lover. 
Tetiana Prentkovych - 1, 2 million subscribers

Tetiana Prentkovych is not only a successful blogger, but also the mother of her son Ivan and a businesswoman. She started developing her blog back in 2012. According to her, her husband created a profile for her. Then the red-haired girl from Ternopil with a husky dog and tattoos on her body began to attract the attention of fans. Together with her husband Orest, the couple opened their first business - an Asian restaurant Tiger. Later, Tania began to outgrow Ternopil, so she moved with her family to Kyiv, where she set up her own PRentkovych agency. However, after some time in Kyiv the famous couple Tania Prentkovych and Orest Murii shocked the subscribers by announcing that they were divorcing. Despite numerous scandals on Instagram and the Internet, both have found happiness and are now sharing happy moments of life with their fans again.

\section{Alina Frendii - 1.1 million subscribers}

Alina Frendii is a well-known blogger from Ternopil. The girl is known for her style, so she interested the audience with her stylish outfits. Despite this, supporters watched closely the love story of Alina and Petro Zastavnyi, the son of the former mayor of Ternopil. In 2018, the lovers had a magnificent wedding in Ternopil, and later moved to Kyiv. Alina founded her own clothing brand TOTE, and later made fans happy with the news of her pregnancy. Now happy parents are raising their son Yan, and Alina often shares the secrets of motherhood with her subscribers. She also shares style tips and beautiful photos from travelling.

The Internet-resources constantly provide information about popular or new blogs (Top, 2021).

The Internet-resources produce topics for successful blogs (Top 25, 2021). For example, among the most common are: reviews, articles-manuals, beginner's guide, recipes, news, tips, travel, fitness, self-defense, do-it-yourself, video games, gardening, photography, selections of interesting websites, learning tools, language learning, web design, interior designer, sports, animals, self-improvement, self-employment, public speaking, modest life, 
exchange of stories, etc. But these suggestions usually have no negative comments on the creativity of bloggers, time constraints, and so on. Therefore, we see in the issue of blogging a number of debatable issues for further discussion.

Conclusion. The blogs provide journalists with a quick connection with the audience, here they communicate with readers, encourage them to open dialogue. The blogs affect the quality of traditional media. Blogging and journalism are two heterogeneous types of mass information and communication activities, between which there is much in common and different, but the same moral responsibility for content.

The blogs are powerful producers of information and, as a consequence, correlators of network information flows.

The websites and social networks systematically provide rankings of the most popular blogs. In such cases, the authors, their age, number of subscribers, topics and a short history of the author are shown, and details of the private life of bloggers are usually displayed.

We see the prospects of the research in the further study of blogs as a communication activity, in particular the latest means that attract the attention of listeners and viewers.

\section{ДЖЕРЕЛА ТА ЛІТЕРАТУРА}

1. 10 найпопулярніших українських блогерів в Instagram: що про них відомо. 4 листопада 2020. URL: https:// lifestyle.24tv.ua/10-naypopulyarnishih-ukrayinskih-blogerivnovini-shou-biznesu_n1450510.

2. 25 кращих тем для нового блогу. 9 червня 2021 URL: https://www.imena.ua/blog/25-topics-for-a-new-blog/.

3. Артамонова I. Тенденції становлення та перспективи розвитку інтернет-журналістики в Україні. Донецьк : Лебідь, 2009. 416 c.

4. Голубовський P. Місцева жовта преса. URL: http://blog.golubovsky.com/chuck-norris-ontario/\#more-3968. 
5. Городенко Л. Новітні медіа: мережеві інформаційнокомунікаційні ресурси; [монографія]. Київ : Академія Української Преси, 2010. 172 с.

6. Городенко Л. Теорія мережевої комунікації; [монографія]. Київ : Академія Української Преси, 2011. 387 с.

7. Екгард Л. В. Блогерство - гражданская журналистика или сплетни. Вестн. Воронеж. гос. ун-та. 2010. С. 220-223.

8. Іванова О. М. Профессионализация интернетжурналистики в блогосфере: автореф. канд дисс. социол. наук. Москва, 2011. URL: http://www.dissercat.com/ content/ professionalizatsiya-internet-zhurnalistiki-v-blogosfere.

9. Квіт С. М. Нові медіа. Масові комунікації. URL: http://libfree.com/199901197_zhurnalistikanovi_mediyi.htmlhttp://1 ibfree.com/199901197_zhurnalistikanovi_mediyi.html.

10. Кісса Ю. Блоги - це неформальна журналістика. URL: (http://www.personal-trening.com/blog).

11. Коваленко О. Д. Розвиток IР-технологій та нові можливості (громадянської) журналістики. URL: http:// diploma.j-school.kiev.ua/blog/kovalenko-olenadyplom2006/.

12. Потятиник Б.В. Інтернет-журналістика. Львів : ПАЇС, 2011. С. 21-25.

13. Семенченко М. Про low-cost журналістику. День. 2011, 9 грудня. С. 1. URL: www.day.kiev.ua/220432/.

14. Топ-4 цікавих українських блоги. 9 червня 2021. URL: https://p-p.com.ua/news/top-4-tsikavykh-ukrainskykh-blogy/.

15. New media URL: http://en.wikipedia.org/wiki/New_media\# cite note-3.

\section{REFERENCES}

1. 10 naipopuliarnishykh ukrainskykh bloheriv v Instagram: shcho pro nykh vidomo (2020). [10 most popular Ukrainian bloggers on Instagram: what do we know about them]. 4 lystopada. Retrieved from https://lifestyle.24tv.ua/10-naypopulyarnishihukrayinskih-blogeriv-novini-shou-biznesu_n 1450510 Ukrainian]. 
2. 25 krashchykh tem dlia novoho blohu (2021). [25 best topics for new blog]. 9 chervnia Retrieved from https://www.imena.ua/ blog/25-topics-for-a-new-blog/ [in Ukrainian].

3. Artamanova, I. (2009). Tendentsii stanovlennia ta perspektyvy rozvytku internet-zhurnalistyky v Ukraini [Tendencies and prospects for the development of online- journalism in Ukraine]. Donetsk : Lebid, 416 [in Ukrainian].

4. Holubovskyi, R. Mistseva zhovta presa (2021). [Local tabloids]. Retrieved from http://blog.golubovsky.com/chuck-norrisontario/\#more-3968 [in Ukrainian].

5. Horodenko, L. (2010). Novitni media: merezhevi informatsiino-komunikatsiini resursy; [monohrafiia] [Modern media: network informational and communicative resources; monograph]. Kyiv : Akademiia Ukrainskoi Presy, 172 [in Ukrainian].

6. Horodenko, L. (2011). Teoriia merezhevoi komunikatsii; [monohrafiia] [Theory of network communication; monograph]. Kyiv : Akademiia Ukrainskoi Presy, 2011. 387 [in Ukrainian].

7. Ekhard, L. (2010). V. Bloherstvo - hrazhdanskaia zhurnalistika ili spletni [Blogging is a civic journalism or rumors]. Vestn. Voronezh. hos. Un-ta, 220-223 [in Ukrainian].

8. Ivanova, O. M. (2011). Professionalyzatsiia internetzhurnalystiki v blohosfere [Professionalizing online-journalism in the blogosphere]: avtoref. kand dyss. sotsyol. nauk. Moskva, 2011. Retrieved from http://www.dissercat.com/content/ professionalizatsiya-internet-zhurnalistiki-v-blogosfere [in Ukrainian].

9. Kvit, S. M. (2021). Novi media. Masovi komunikatsii [New media. Mass communication]. Retrieved from http:// libfree.com/199901197_zhurnalistikanovi_mediyi.htmlhttp://libfree .com/199901197_zhurnalistikanovi_mediyi.html [in Ukrainian].

10. Kissa, Y. Blohy - tse neformalna zhurnalistyka (2020). [Blog is an informal journalism]. Retrieved from http://www.personaltrening.com/blog [in Ukrainian]. 
11. Kovalenko, O. D. Rozvytok IP-tekhnolohii ta novi mozhlyvosti (hromadianskoi) zhurnalistyky [Development of IPtechnology and new possibilities (civic) journalism]. Retrieved from http://diploma.j-school.kiev.ua/blog/kovalenko-olenadyplom2006/ [in Ukrainian].

12. Potiatynyk, B.V. (2011). Internet-zhurnalistyka [Internetjournalism]. Lviv : PAIS, 2011, 21-25 [in Ukrainian].

13. Semenchenko M. (2011). Pro low-cost zhurnalistyku [About low-cost journalism]. Den. 2011, 9 hrudnia, 1. Retrieved from www.day.kiev.ua/220432/ [in Ukrainian].

14. Top-4 tsikavykh ukrainskykh blohy [Top 4 interesting Ukrainian blogs]. 9 chervnia 2021. Retrieved from https://pp.com.ua/news/top-4-tsikavykh-ukrainskykh-blogy/ [in Ukrainian].

15. New media (2020). Retrieved from http://en.wikipedia.org/ wiki/New_media\#cite_note-3 [in Ukrainian].

\section{ABSTRACT}

The information scope of the last decade has been realized in the integration of various ways of communication into interactive information networks. Combining texts, images, symbols and sounds in one system in a global network and providing accessible and inexpensive access, dramatically changes the nature of social communication.

The history of journalism has its stages of development: from ancient to modern forms, from signs to modern information technologies. If the previous centuries are properly described and analyzed by the researchers, the new means of communication require more study.

The proposed study attempts to analyze blogs as new means in modern communication.

Blogging is somewhat different from journalism in its predominant communicative function, which in traditional media is only available live on radio and television, but information is often censored by a moderator, an editor, who determines who to broadcast and when to do it. 
The study focuses on whether a blog is a form of new journalism or a new journalistic genre that has entered mass communication.

The article as an applied aspect considers ten most popular Ukrainian bloggers on Instagram based on the results of the analysis of online publications.

It is concluded that the blogs are powerful producers of information and, as a consequence, correlators of network information flows.

Blogging and journalism are two types of mass information and communication activities, between which there are common and different, but both types have a moral responsibility for the content.

The websites and social networks systematically provide rankings of the most popular blogs. In such cases, the authors, their age, number of subscribers, topics and a short history of the author are shown, and details of the private life of bloggers are usually displayed. It attracts the attention of the consumer of information.

Keywords: blog, personal blog, thematic blog, historical stages of journalism, communication, new media, new communication technologies, Internet.

\section{АННОТАЦИЯ}

Информационная сфера последнего десятилетия реализовалась в интеграции различных способов коммуникаџии в интерактивные информационные сети. Объединение в одной системе текстов, изображений, символов и звуков в глобальной сети и с доступным и недорогим доступом, кардинально меняет характер социиальных коммуникации.

История журналистики имеет свои этапь развития: от древних до современных форм, от знаков к современным информационным технологиям. Если предыдущуие века соответствуюшим образом описань и проанализировань ученьми, то новые средства коммуникации требуют отдельных исследований. 
B предлагаемой студии предпринята попьтка проанализировать блоги как новые средства в современной коммуникации.

Блогерство - отличается от журналистики тем, что в нем доминантной является коммуникативная функичи, в традиционньх средствах массовой коммуникации только во время прямого эфира на радио, телевидении, но часто поддающзаяся цуензуре информация модератором, редактором, который определяет кого, когда выпустить в эфир.

В статье акиентируется внимание на том, есть ли блог видом новой журналистики или новым журналистским жанром, который вошел в массовую коммуникацию.

В статье как прикладной аспект рассмотрен десять cамых популярных украинских блоггеров в Instagram nо результатам анализа интернет-изданий.

Сделаны выводы, что блоги являются мошныли производителями информации и, как следствие, -коррелятор сетевых информационных потоков.

Блогерство и журналистика - два вида массовой информационно-коммуникационной деятельности, между которыми есть общее и отличное, но оба вида имеют моральную ответственность за контент.

Интернет-сайты и соииальные сети систематически подают рейтинги самых популярных блогов. В таких случаях подают автора, его возраст, количество подписчиков, темь и короткую историю автора, обычно подают детали частной жизни блогеров. Такая структура подачи материала привлекает внимание потребителя информации.

Ключевые слова:, блог, личный блог, тематический блог, исторические этапь журналистики, коммуникация, новые медиа, новые коммуникационные технологии, Интернет. 